\title{
Examining Overreaction in Indian Stock Market for Quarterly News
}

\section{Dr. Sitangshu Khatua}

Heritage Business School, Kolkata, India | e-mail: sitangshu k@yahoo.com

\section{Dr. Hemant Kumar Pradhan}

XLRI, Jamshedpur, India | e-mail: pradhan@xlri.ac.in

Volume 4 No 1 (2014) ｜ ISSN 2158-8708 (online) ｜ DOI 10.5195/emaj.2014.57 | http://emaj.pitt.edu |

\section{Abstract}

Market Overreaction is a very familiar and age-old craze amongst traders. Pigou (1929) defined it as a 'conducting rod along which an error of optimism or pessimism, once generated, propagates itself about the business world.' The question of whether or not Indian stock prices market is overreacted during any stock-specific news is best answered by a comprehensive and concurrent analysis of the various tests and data available while using the event study.

This study wants to address the impact of size, volatility and asymmetry in the terms of investors' overreaction to the firm-specific news not only individually but also jointly. The outcome of this study helps to solve the problem concerning the extent to which quarterly announcements have informational content, and whether the investors are affected by the signals. The present study substantiates the policy recommendation for the market players as well as for the analysts in estimating earning announcement events under different market condition and different market capitalization value of the firm.

Keywords: Overreaction, Event Study, Abnormal Return, Cumulative Abnormal Return, Market Model, Quarterly Announcements.

\section{$(\mathrm{cc}) \mathrm{BY}$}

New articles in this journal are licensed under a Creative Commons Attribution 3.0 United States License.

\section{ULLS D-Sorke}

This journal is published by the University Library System of the University of Pittsburgh as part of its D-Scribe Digital Publishing Program, and is cosponsored by the University of Pittsburgh Press. 


\section{Examining Overreaction in Indian Stock Market for Quarterly News}

\author{
Dr. Sitangshu Khatua
}

Dr. Hemant Kumar Pradhan

\section{Introduction}

Any event in which there is an abnormal stock price movement followed by a correction in the reverse direction can be taken as evidence of overreaction. In a seminal paper De Bondt and Thaler (1985) first coin a term, called "overreaction" in the stock market and prove that, as is the case with many other human activities, financial markets show an excessive reaction to new information or unexpected events. They conclude that a price reversal (negative returns) may be anticipated by the evidence of extreme preceding positive returns. Alternately, an upward overreaction subsequently calls forth a dramatic downward adjustment or correction.

The question of whether Indian stock prices market is experiencing overreaction is best answered by a comprehensive and concurrent analysis of the various tests and data available while using the event study for any anticipated stock-specific news like quarterly announcements. The present study has found how the investors' response will vary with market condition or uncertainty of market to firmspecific news and their reaction will change with size of the firm.

\section{Literature Review}

In their seminal paper, Ball and Brown (1968) have established that there is some association between information contained in the firm's accounting income numbers and stock prices. They identify that about $10-15 \%$ of the information contained in announced earnings had been predicted by the month of preliminary declaration. There are some studies illustrating more firm-specific factors. Grant (1980) finds that the market in which stocks are traded often establish the behavior of securities return during the earning announcements and these behaviors also change due to change in announcement policy (Beneish and Whaley,1996). Lacina et al. (2009) investigate the association between abnormal stock returns around earnings announcement dates and quarterly foreign and domestic sales and earnings data.

Freeman (1987) has established that the amount of unpredicted news transferred to the market by earnings report is inversely proportional to the market capitalization or the size of the firm. Lev and Penman (1990) also indicate that larger firms report more earning forecast than smaller firms. Previous researchers (Lang and Lundholm,1993) infer that uncertainty can act as a proxy for information asymmetry.
They investigate cross-sectional variation in analysts' published evaluations of firms' disclosure practices and provided evidence that the analysts' ratings are increasing in firm size and in firm performance as measured by earnings and return variables. Ratings decrease in the correlation between earnings and returns and these are higher for firms issuing securities in the current or future period.

Veronesi (1999) has built up his model by introducing the significant impact of current market uncertainty on the extent of investor's reaction to good or bad firm-specific news. According to this paper, investors rationally predict that their anticipations of cash flows tend to react more quickly to news during high uncertain periods. This higher sensitivity to news tends to increase the volatility of stock price. That is the reason behind the tendency of investors to hedge, because generally they are risk-averse. According to this model, investors discount good news at a higher rate if it is announced during bad times, and investors discount bad news at a much higher rate if it is announced during good times. Several studies document that economic and market conditions influenced the investor's reactions to any identical events (Da Costa, 1994; Boyd et al., 2001). Docking and Koch (2005) find that dividend change announcements to lower dividends are followed by greater decrease in stock price during uncertain and up market. Announcements to increase dividends i.e. good news tends to be considered as better news in a normal or down market with high volatility. Whereas in the case of decreasing dividends announcements investors overreact more strongly to bad news in good times. They prescribe an implication by using dynamic rational expectations equilibrium model (Veronesi's Model,1999) with behavioral considerations that link the investors' reactions to market direction and volatility. The study of Johnson and Stretcher (2009) shows that excess stock return around the stock split announcements vary depending on the level of market volatility. Negative news has more impact on the variance of return or volatility than positive news (Pradhan and Narashimhan, 2002).

Following section develops hypotheses and methodologies. Section 4 illustrates the data sources. Section 5 depicts results and section 6 reports additional feature to capture overreaction effect. Section 7 concludes.

\section{Hypothesis}

In the present study we have tested following hypotheses to capture how overreaction effects differ across stocks, market conditions and the content of news. The reasons behind the differences in overreaction may be driven by variation in Size of the firm, Volatility of stock return , the content of the news and also the combined impact of the above three variables. The following tests have been done for considering the three effects like size, volatility and news individually and the combinations of any two effects combined to measure market over-reaction.

\subsection{Size Effects}

Large size firms are less vulnerable of marketturmoil because of their volume, turn-over and selfmonitoring capacity. Atiase (1985) and Freeman (1987) 
established that the amount of unpredicted news transferred to the market by earnings report is inversely proportional to the market capitalization or the size of the firm. Lev and Penman (1990) also indicated that larger firms report more earning forecast than smaller firms. The present study also investigates whether there are any significant differences between Cumulative Abnormal Return (CAR) of the large and small size firms. In order to distinguish between CAR of small and large size stocks the following regression test has been done:

$\mathrm{CARi}=\mathrm{b} 0 * \mathrm{SS}+\mathrm{b} 1 * \mathrm{MS}+\mathrm{b} 2 * \mathrm{LS}$

The dummy variables are defined in the following manner. The coefficients are indexed as: $b i=1$ if the event occurs during size quartile $\mathrm{i}$ and 0 otherwise; Where, $\mathrm{SS}$ (Small Size) $=0$ if the event occurs when firm's market capitalization value is less (bottom 25 percentile) ; MS(Medium Size) $=1$ if the event occurs when firm's market capitalization value is medium (middle 50 percentile) and LS(Large Size) $=2$ if the event occurs when firm's market capitalization value is more (top 25 percentile).

Hypothesis H1: There is significant difference in the mean $C A R$ 's of small and large size firm $(b 0 \neq b 2)$.

\subsection{Volatility Effects}

Market turbulence may instigate overreaction. That is why, dividend change announcements to lower dividends are followed by greater decrease in stock price during uncertain, volatile market (Docking and Koch, 2005). Johnson and Stretcher (2009) also establish that excess stock return around the stock split announcements vary depending on the level of market volatility. In order to determine the difference in the CAR between high and low volatility periods the regression equation is as follows:

$\mathrm{CARi}=\mathrm{b} 0 * \mathrm{LV}+\mathrm{b} 1 * \mathrm{MV}+\mathrm{b} 2 * \mathrm{HV}$

The dummy variables are defined in the similar manner. The coefficients are indexed as: $b i=1$ if the event occurs during volatility quartile $\mathrm{i}$ and 0 otherwise; Where, $\mathrm{LV}($ Low Volatility) $=0$ if the event occurs when market is less volatile (bottom 25 percentile); MV(Medium Volatility) $=1$ if the event occurs when market is medium volatile (middle 50 percentile) and $\mathrm{HV}$ (High Volatility) $=2$ if the event occurs when market is more volatile (top 25 percentile).

Hypothesis H2: There is significant difference in the mean $C A R$ 's in low volatility and high volatility period $(b 0 \neq b 2)$.

\subsection{News Effects}

People react more on any negative news rather than any positive news. Negative news has more impact on the variance of return or volatility than positive news ( Pradhan and Narashimhan, 2002). In order to differentiate between
CAR of good news and bad news the following regression equation has been tested:

$\mathrm{CARi}=\mathrm{b} 0 * \mathrm{GN}+\mathrm{b} 1 * \mathrm{NN}+\mathrm{b} 2 * \mathrm{BN}$

The dummy variables are defined in the similar manner. The coefficients are indexed as: $b i=1$ if the event occurs during news quartile $\mathrm{i}$ and 0 otherwise; Where, $\mathrm{GN}($ Good News $)=0$ if the event occurs when AR is more than positive $2.5 \%$; NN(No News) $=1$ if the event occurs when $\mathrm{AR}$ is less than negative $2.5 \%$ and $\mathrm{BN}$ (Bad News) $=1$ if the event occurs when $\mathrm{AR}$ is in between negative $2.5 \%$ to positive $2.5 \%$.

Hypothesis $\mathbf{H 3}$ : There is significant difference in the mean $C A R$ 's of good news and bad news events $(b 0 \neq b 2)$.

\subsection{Combined Effects}

Earlier studies document that above size, volatility and news - all three variables individually influence on the movement of stock price during any news arrival. To extend it further, the present study also tries to investigate the consequences of the all possible combined or cross effects of two variables out of the above three on market overreaction.

To test for the possibility that size and volatility do not have independent effects on stock performance, a regression model has been formed using the CAR as the dependent variable and a set of nine dummy variables representing the cross products of the three volatility dummies and the three size dummies as independent variables.

CARi $=$ b00*LV_SS + b01*LV_MS + b02*LV_LS + b10*MV_SS + b11*MV_MS + b12*MV_LS + b20*HV_SS + b21*HV_MS + b22*HV_LS

Where, LV_SS = Low Volatility*Small Size.

The other dummy variables are defined in a similar manner. The coefficients are indexed as: $b i j=1$ if the event occurs during volatility quartile $\mathrm{i}$ and size quartile $\mathrm{j}$, and 0 otherwise; Where $\mathrm{i}=0$ (LV), 1 (MV), or 2 (HV) and where $\mathrm{j}=0$ (SS), 1 (MS), or 2 (LS).

Hypothesis H4: There is significant difference in the mean CAR's in low volatility and high volatility period for small size firms $(b 00 \neq b 20)$.

Hypothesis H5: There is significant difference in the mean CAR's in low volatility and high volatility period for large size firms ( $b 02 \neq b 22)$. 
To test for the possibility that other probable pairs like volatility and news and size and news have combined effects on stock performance, following regression model for each is to be tested:

CARi $=$ b00*LV_GN + b01*LV_NN + b02*LV_BN + b10*MV_GN+ b11*MV_NN + b12*MV_BN + b20*HV_GN $+\mathrm{b} 21 * \mathrm{HV} \_\mathrm{NN}+\mathrm{b} 22 * \mathrm{HV} \_\mathrm{BN}$

Hypothesis H6: There is significant difference in the mean CAR's for good news and bad news events in low volatility period $(b 00 \neq b 20)$.

Hypothesis H7: There is significant difference in the mean CAR's for good news and bad news events in high volatility period $(b 00 \neq b 20)$.

CARi $=$ b00 $*$ GN_SS + b0 $1 *$ GN_MS + b02 $*$ GN_LS + b10* NN_SS + b11*NN_MS + b12* NN_LS + b20* BN_SS + b21*BN_MS + b22*BN_LS

Hypothesis H8: There is significant difference in the mean CAR's for good news and bad news events for small size firm( $b 00 \neq b 20)$

Hypothesis H9: There is significant difference in the mean CAR's for good news and bad news events for large size firm( $b 00 \neq b 20)$.

\subsection{Methodology}

Under general conditions ordinary least squares (OLS) is a consistent estimation procedure for the market model parameters (Mackinlay, 1997). For the $\mathrm{i}^{\text {th }}$ firm in event time, the OLS estimators of the market model parameters for an estimation window of observations are:

$$
\widehat{\beta_{\mathrm{i}}}=\frac{\sum_{\mathrm{t}=\mathrm{T}_{0}+1}^{\mathrm{T}_{1}}\left(\mathbf{R}_{\mathrm{it}}-\widehat{\mu}_{\mathrm{i}}\right)\left(\mathbf{R}_{\mathrm{mt}}-\widehat{\mu_{\mathrm{m}}}\right)}{\sum_{\mathrm{t}=\mathrm{T}_{0}+1}^{\mathrm{T}_{1}}\left(\mathrm{R}_{\mathrm{mt}}-\widehat{\mu_{\mathrm{m}}}\right)^{2}}
$$

$$
\widehat{\alpha_{i}}=\widehat{\mu_{i}}-\widehat{\beta_{i}} \widehat{\mu_{m}}
$$

(2)

$$
\begin{aligned}
& \widehat{\sigma_{s_{1}}^{2}}=\frac{1}{\mathrm{~L}_{1}-2} \sum_{\mathrm{t}=\mathrm{T}_{0}+1}^{\mathrm{T}_{1}}\left(\mathbf{R}_{\mathrm{it}}-\widehat{\alpha_{\mathrm{i}}}-\widehat{\beta_{\mathrm{i}}} \mathbf{R}_{\mathrm{mt}}\right)^{2} \\
& \widehat{\mu_{\mathrm{i}}}=\frac{1}{\mathrm{~L}_{1}} \sum_{\mathrm{t}=\mathrm{T}_{0}+1}^{\mathrm{T}_{1}} \mathrm{R}_{\mathrm{it}}
\end{aligned}
$$

$$
\widehat{\mu_{\mathrm{m}}}=\frac{1}{\mathrm{~L}_{1}} \sum_{\mathrm{t}=\mathrm{T}_{\mathrm{O}^{+}}}^{\mathrm{T}_{1}} \mathrm{R}_{\mathrm{mt}}
$$

$\mathrm{T}_{0}+1=-111$ days and $\mathrm{T}_{1}=-11$ days, therefore $\mathrm{L}_{1}=100$ days.

$\mathbf{R}_{\text {it }}$ and $\mathbf{R}_{\mathbf{m t}}$ are the return in event period t for security $i$ and the market $m$ respectively.
From the market model, one can measure and analyze the abnormal returns $\left(A R_{i t}\right)$. Let $A R_{i t}, t=T_{1}, \ldots . ., T_{2}$, be the sample of $\mathrm{L}_{2}$ abnormal returns for firm $\mathrm{i}$ in the event window.

$$
\mathrm{AR}_{\mathrm{it}}=\mathrm{R}_{\mathrm{it}}-\left(\widehat{\alpha_{\mathrm{i}}}+\widehat{\beta_{\mathrm{i}}} \mathrm{R}_{\mathrm{mt}}\right)
$$

Example of the use of OLS parameters can be found in DeAngelo et al. (1984); Mikkelson and Partch (1986). To capture overall impact of the event on security price the abnormal return has to be aggregated along two directions Through time for an individual stock and then aggregation, both across securities and time. But, because of overlapping of event windows there are clustering effects. This has been compensated by using portfolio approach (Mackinlay, 1997).

A testing framework is defined for calculation of abnormal returns. For this, the null hypothesis is defined and the technique of aggregating the individual firm's abnormal return is determined. Say, for testing of an event on several firms, an equally weighted or value weighted portfolio may be constructed. The cumulative abnormal return (CAR) is defined as the sum of abnormal returns for each day in the event window.

$C A R_{j}=\sum_{\mathrm{t}=\mathrm{T}_{1}}^{\mathrm{T}_{2}} A R_{\text {it }}$

After finding out $\mathrm{AR}_{\mathrm{it}}$ for each day in an event, all $\mathrm{AR}_{\mathrm{it}} \mathrm{s}$ are aggregated and computed CAR for each event.

\section{Data}

The main data in this study consist of daily closing returns of stocks, earning announcement dates, daily closing market returns.

\subsection{Preliminaries: Data Source, Study Period, Sample}

In the present study, quarterly earnings announcement dates for 50 firms listed in NSE (National Stock Exchange) of India for the period of Oct' 2005 to Nov' 2010 has been taken from CMIE (Centre for Monitoring Indian Economy) Prowess database and NSE. These announcements correspond to the quarterly earnings for the third quarter of 2005 - 2006 and second quarter of 20102011. This period (2005-2010) has been the most eventful era not only for the Indian security market but the global stock market as well. In this period of study, Indian market has taken major strides to make an important place for itself in the entire world security market. Within this span of five years, market experienced long term effects of after globalization, world recession and its impact and the post-recessional recovery as well. The present study wants to examine the overreaction effect for stock specific anticipated news, for which we have taken quarterly disclosure dates of the firms as event dates. The announcement dates are considered here as the event dates not the grapevine dates or the effective dates of any announcements. 
The five years data for fifty firms provide a total sample of 822 available announcements. For 20 quarters of 50 companies, data for total 1000 quarters is available. But out of these, 822 have been taken. In selection of sample firms the followings are taken into consideration. For this type of event studies, frequently traded stocks should be taken, that is why NSE-50 stocks are considered for this study. 50 stocks listed in NSE cover more or less all the leading firms across various industries or sectors. Financial Year 2008-2009 is considered as the base year, keeping in mind the impact of global recession during this time. It means if a firm is enlisted in NSE in this particular year, then only it is included in the sample. Few stocks are not considered for this study because of non-availability of data for the entire period like the stocks of Reliance Power, Bajaj Auto and Power Grid Corporation. To select the stocks one basic rule has been maintained, i.e. out of available 17 quarters, data of 14 quarters (70 percent) should be available properly. To capture the impact of the news independently, if any other major events happened during the defined event window (21 days), those event dates have not been included in the present sample. In this way impact of confounding effects are removed. This filtering process, we believe, ensures the robustness of results even though wide varieties of firms have not been considered. Sometimes firms announce financial report for more than one quarter on a single date. Such announcements are also not included in this sample. Sometimes the firms do not announce report for a particular quarter. For each firm and quarter three types of information are required. They are date of announcement, the actual earnings and the measure of the expected earnings. The market index is considered as S\&P CNX Nifty (Standard and Poor's CRISIL NSE Index) or Nifty Fifty. For both the stocks as well as market index, adjusted daily closing price and returns have been considered. Earlier studies start with annual, semi-annual (Obaidullah,1990) and monthly returns (Fama et al., 1969). Gradually there are developments in considering more frequent data. That is why daily closing prices are taken for this study. Impact of other stock specific events like announcement of bonus, dividend etc. are already adjusted by taking the adjusted closing price of the stock. The next step is the measure of expected earnings as per normal return model which can be estimated by using Market model as discussed earlier.

\subsection{Windows Specifications}

Next stage is to specify the percentage change in the stock return. For this, an event window and an estimation window have to be specified. In this study the observation interval is one day, i.e., daily stock returns will be used. A 21 day event window will be considered comprising of 10 preevent days, the event day and 10 post-event days. According to the earlier research event window should be as less as possible to get good statistical results. For selecting the event window a detailed sensitivity analysis has been done by choosing the event windows from 3 days $(-1$ to +1$), 7$ days $(-$ 3 to +3 ), 21 days ( -10 to +10 days), 31 days $(-15$ to +15$)$ and 41 days $(-20$ to +20$)$ and patterns are found. Out of these, 21 days $(-10$ to +10$)$ are taken for final sample which gives a better pattern of CAR plot in the case of good news, bad news and no news (Mackinlay,1997). For each announcement 100 trading day period prior to the event window will be used as the estimation window (MacKinlay,1997). It is typical for the estimation window and the event window not to overlap to make the procedure robust. Ideally for a quarter 100 days plus 21 days comprises 171 trading days which almost covers one quarter. This design provides estimators for the parameters of the normal return model which are not influenced by the returns around the event. Including the event window in the estimation of the normal model parameters could lead to the event returns having a large influence on the normal return measure. In this situation both the abnormal returns and the normal return would capture the event impact. This would be problematic because the methodology is built around the assumption that the event impact is captured by the abnormal returns. On occasions, the post event window data is included with the estimation window data to estimate the normal return model. The goal of this approach is to increase the robustness of the normal market return measure to gradual changes in its parameters.

\subsection{Sample Classifications}

Size: In this study size effects are to be examined. Nifty Junior (100) stocks could be the ideal choice for small firms to study size effects. But preconditions of the event study are that all stocks should be very frequently traded in the market and selected stocks cover all industry verticals existing in the market on an average. That is why, Nifty Fifty stocks are selected to fulfill these conditions. The variation of daily Market Cap of Nifty Fifty stocks during the period of study (2005-10) is huge. If the daily market cap is considered across the study period, the highest stock is about 215 times that of the lowest. Thus the size effects can be studied with considerable precision using the Nifty-Fifty stocks.

Accordingly ranking has been done on the basis of market capitalization or size of each stock on the event date. Top 25 percentile has been considered as large size firm, bottom 25 percentile as small size firm and the middle 50 percentile as medium size firm (Lev and Penman,1990).

Volatility: The investors' forecasts of expected market trend and volatility are a function of current market and uncertainty. For the pre-announcement period (10 days), the mean and standard deviation of daily stock return of each announcement have been calculated and then ranked according to the standard deviation, and partitioned into quartiles. The high-volatility market is then defined as the top quartile, the low- volatility as the lowest quartile and the 
medium-volatility market as the middle 50 percentile (Docking and Koch, 2005).

News or Asymmetry: If the actual earnings are more than the expected earnings with respect to any announcement, it can be categorized into good, bad or no news or noise. If the actual exceeds expected by 2.5 percent the announcement is designated as good news, and if the actual is 2.5 percent less than the expected the announcement as designated as bad news. Those announcements where the actual earnings is in the 5 percent range centered about the expected earnings are designated as no news or noise (MacKinlay,1997). It has been seen that there is a total variation between actual and expected daily earnings to the extent of +5 to -5 percent approximately in the case of all 50 stocks in NSE for the current 5 years. Out of total 822 quarterly earnings announcements 206 are good news, 206 are bad news and rest 410 are no news or noise. For every categorization, all events have been analyzed separately for good news, bad news and no news. Sampling is given in table 1 (Prabhala, 1997).

Table 1: Sampling of data

\begin{tabular}{|c|c|c|c|c|c|}
\hline & & \multicolumn{3}{|l|}{ News } & \multirow[t]{2}{*}{ Total } \\
\hline & & $\begin{array}{l}\text { Bad } \\
\text { News }\end{array}$ & $\begin{array}{l}\text { No } \\
\text { News }\end{array}$ & $\begin{array}{l}\text { Good } \\
\text { News }\end{array}$ & \\
\hline \multirow[t]{4}{*}{ Volatility } & Low Volatile & 39 & 127 & 39 & 205 \\
\hline & Medium Volatile & 102 & 204 & 101 & 407 \\
\hline & High Volatile & 65 & 79 & 66 & 210 \\
\hline & Total & 206 & 410 & 206 & 822 \\
\hline \multirow[t]{4}{*}{ Size } & Small Size & 45 & 94 & 66 & 205 \\
\hline & Medium Size & 111 & 212 & 89 & 412 \\
\hline & Large Size & 50 & 104 & 51 & 205 \\
\hline & Total & 206 & 410 & 206 & 822 \\
\hline \multirow[t]{5}{*}{ Volatility } & & $\begin{array}{l}\text { Small } \\
\text { Size }\end{array}$ & $\begin{array}{l}\text { Medium } \\
\text { Size }\end{array}$ & $\begin{array}{l}\text { Large } \\
\text { Size }\end{array}$ & \\
\hline & Low Volatile & 51 & 103 & 51 & 205 \\
\hline & Medium Volatile & 102 & 204 & 101 & 407 \\
\hline & High Volatile & 52 & 105 & 53 & 210 \\
\hline & Total & 205 & 412 & 205 & 822 \\
\hline
\end{tabular}

\subsection{Event Overreactions}

Table 2 : Mean and SD of AR and CAR for "Good News", "Bad News" and "No News" (Using Market Model )

\begin{tabular}{|c|c|c|c|c|c|c|c|}
\hline News & $\begin{array}{l}\text { No. } \\
\text { of } \\
\text { News }\end{array}$ & $\begin{array}{l}\text { Mean } \\
\text { AR }\end{array}$ & $\begin{array}{l}\text { SD } \\
\text { AR }\end{array}$ & SE & $\begin{array}{l}\text { Mean } \\
\text { CAR }\end{array}$ & $\begin{array}{l}\text { SD } \\
\text { CA } \\
\text { R }\end{array}$ & $\begin{array}{l}\theta_{1}= \\
\text { Mean } \\
\text { CAR/S } \\
\text { D CAR }\end{array}$ \\
\hline Good & & 3.9727 & 2.01 & 1.9680 & 3.6756 & 11.4 & 0.3219 \\
\hline News & 206 & 18447 & 8621 & $\begin{array}{l}3609 \\
-\end{array}$ & $\begin{array}{l}80434 \\
-\end{array}$ & 1671 & $\begin{array}{l}56219 \\
-\end{array}$ \\
\hline $\begin{array}{l}\text { No } \\
\text { News }\end{array}$ & 410 & $\begin{array}{l}-0.139 \\
-\end{array}$ & $\begin{array}{l}0.91 \\
9088\end{array}$ & $\begin{array}{l}0.1512 \\
36947 \\
-\end{array}$ & $\begin{array}{l}0.7562 \\
61877 \\
-\end{array}$ & $\begin{array}{l}8.72 \\
7675\end{array}$ & $\begin{array}{l}0.0866 \\
51017 \\
-\end{array}$ \\
\hline $\begin{array}{l}\text { Bad } \\
\text { News }\end{array}$ & 206 & $\begin{array}{l}3.5254 \\
36893\end{array}$ & $\begin{array}{l}1.76 \\
2171 \\
\end{array}$ & $\begin{array}{l}2.0006 \\
20781\end{array}$ & $\begin{array}{l}3.5076 \\
30849\end{array}$ & $\begin{array}{l}10.6 \\
2726\end{array}$ & $\begin{array}{l}0.3300 \\
59625\end{array}$ \\
\hline Total & 822 & $\begin{array}{l}0.0427 \\
61557\end{array}$ & $\begin{array}{l}3.04 \\
9597 \\
\end{array}$ & $\begin{array}{l}0.0140 \\
22037\end{array}$ & $\begin{array}{l}- \\
0.3350 \\
96296\end{array}$ & $\begin{array}{l}10.2 \\
6368 \\
\end{array}$ & $\begin{array}{l}- \\
0.0326 \\
48737\end{array}$ \\
\hline
\end{tabular}

From the above table 2, on the announcement day (Day 0 ) the sample average AR for the "Good News" firm using the market model is $3.9 \%$ and Standard Error is $1.9 \%$ and the value of $\theta_{1}$ is 0.321 where as for the "No News" firm the corresponding values are $-0.139 \%, 0.919 \%$ and -0.086 respectively. This shows that the null hypothesis (the event has no impact) is strongly rejected. The same story repeats for the "Bad News" firms also.

Figure 1: CAR Plot - All "Good News", "No News" and "Bad News" for earning announcements from event day 10 to +10 .

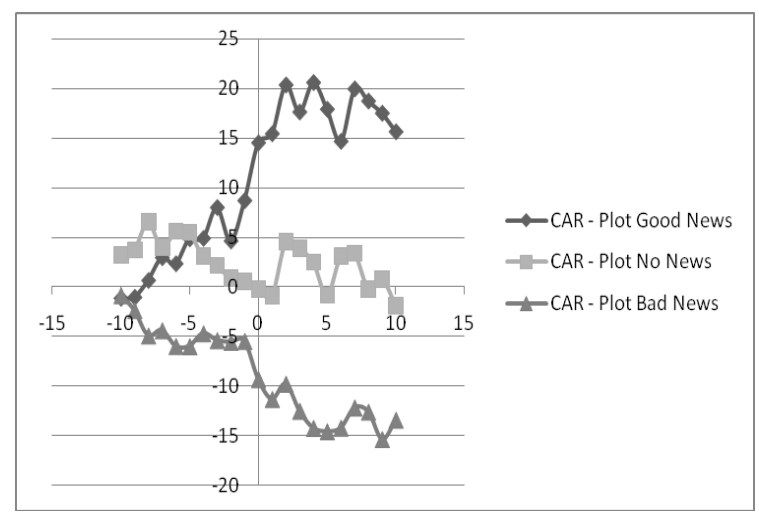

The CAR Plot (figure 1) shows that up to a certain extent the market gradually realizes about the upcoming announcements. That is why the CAR is gradually shifted up in -10 to -1 day for "Good News" and behaves just in opposite manner for bad news over this period. The same trend continues in the post event windows also. 


\subsection{Summary Statistics}

Table 4 provides the summary statistics of preannouncement periods for the sample of 822 quarterly announcements. Events are partitioned by market-cap or size, news category and volatility. For size and volatility, the quartiles partitioning scheme to get the proportioning subsample sizes are used. The news more that +2.5 percent are considered as good news, less than -2.5 percent as bad news and in between these two triggering returns as no news. It is obtained that out of selected 822 quarterly announcements 205 are small size, 412 are medium size and rest 205 are large size. Similarly, 205 events are considered as low volatile, 407 medium and 210 as high volatility. In a similar vein, both 206 events are considered as good news or bad news events. Balance events are termed as no-news.

Table 3: AR and CAR values for Event Days -10 to +10 of

“Good News", "No News" and "Bad News"

\begin{tabular}{|c|c|c|c|c|c|c|}
\hline \multicolumn{7}{|c|}{ Market Model } \\
\hline & Good I & & No Nerms & & Bad Nerts & \\
\hline Day & AR & CAR & AR & CAR & AR & CAR \\
\hline-10 & -1.13 & -1.13 & 3.148276 & 3.14 & -0.84936 & -0.84 \\
\hline .9 & 0.10 & -1.02794279 & 0.533751 & 3675751 & -152599 & -236599 \\
\hline-8 & 1.70 & 0.668665745 & 2.844425 & 6.520176 & -255445 & 492044 \\
\hline-7 & 2.29 & 296334118 & -2.61 & 3910177 & 0.531827 & 438862 \\
\hline-6 & -0.61 & 2354785222 & 1.645144 & 5.555321 & -158588 & -59745 \\
\hline-5 & 252 & 4870083882 & -0.12409 & 5.431231 & -0.02316 & -599766 \\
\hline 4 & 0.04 & 4912907015 & -237851 & 3052716 & 1296517 & 470114 \\
\hline-3 & 3.10 & 8.016168612 & -0.92198 & 2.130735 & -0.08346 & -53846 \\
\hline-2 & -337 & 4.643134812 & -130636 & 0.824377 & -0.18777 & -557237 \\
\hline-1 & 407 & 8.710539751 & -02951 & 0.529281 & 0.100021 & -5.47234 \\
\hline 0 & 5.83 & 1453913323 & -0.83851 & -0.30923 & -3.84742 & .931976 \\
\hline 1 & 0.90 & 15.44361899 & -0.62926 & -0.9385 & -20086 & -113284 \\
\hline 2 & 492 & 2036083277 & 5.433419 & 4.494923 & 1540021 & -9.78835 \\
\hline 3 & -272 & 17.63790204 & -0.05564 & 3.839283 & -2.73879 & -125271 \\
\hline 4 & 296 & 20.60257837 & -1.41185 & 2427431 & -1.72356 & -142507 \\
\hline 5 & -2.69 & 1791326076 & -331514 & -0.88771 & .033475 & -145855 \\
\hline 6 & -324 & 1467811516 & 3952765 & 3.065053 & 0.353121 & -142323 \\
\hline 7 & 529 & 1996565853 & 0.251549 & 3316003 & 2041018 & -121913 \\
\hline 8 & -123 & 18.73826823 & -3.50041 & -0.24381 & -0.42375 & -126151 \\
\hline 9 & -122 & 1751447556 & 0.934776 & 0.690964 & -2.7709 & -15386 \\
\hline 10 & -187 & 1564637944 & -26551 & -1.96413 & 1.960802 & -134252 \\
\hline
\end{tabular}

Examining Overreaction in Indian Stock Market for Quarterly News

Emerging Markets Journal | P a g e $\mid 6$ 
Table 4: Summary Statistics for the 822 quarterly announcements

\begin{tabular}{|c|c|c|c|c|c|c|c|c|c|c|c|}
\hline & $\mathrm{s}$ & s $\sin (a)$ & करज्ञ(i) & 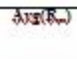 & क्जि(R) & SD(R, & SD(R) & $\begin{array}{l}\text { Mean } \\
\text { (AR) }\end{array}$ & SD (AR) & $\begin{array}{l}\text { Mean } \\
\text { (CAR) }\end{array}$ & $\begin{array}{l}\text { SD } \\
\text { (CAR) }\end{array}$ \\
\hline \multicolumn{12}{|c|}{ Pavel1. Srandarket Cap } \\
\hline \$s & 205 & 0.01 & 091 & 024 & 2079 & 23505 & 4.25049 & 0.35 & 3341 & 031 & 71575 \\
\hline ass & 412 & 0.06 & 101 & -0.17 & -0.27 & 231176 & 3.58157 & .0 .23 & 2935 & -0.64 & 10332 \\
\hline Is & 205 & 0.05 & 0.96 & 0.04 & 0.17 & 24449 & 3.602 & 0.15 & 2883 & .0 .27 & 79831 \\
\hline \multicolumn{12}{|c|}{ Padel I. Tolanifiry } \\
\hline $\mathrm{DV}$ & 205 & 0.05 & 095 & $-\infty 068$ & 005 & 11521 & 274006 & 0.05 & 2456 & -029 & 72163 \\
\hline MN & 407 & 0.05 & 0.98 & 0.04 & 0.10 & 1.8938 & 3.54095 & 0.03 & 2850 & -0.62 & 9.6256 \\
\hline $\mathrm{HV}$ & 210 & 0.04 & 099 & .0 .04 & 0.16 & 3.8571 & 5.41563 & 0.14 & 3.859 & 0.50 & 13349 \\
\hline \multicolumn{12}{|c|}{ PavelC. Tolatiaty and Sire } \\
\hline $\mathrm{IV}_{-} \mathrm{SS}$ & 3 & -001 & 039 & on & 0.05 & 11661 & 24215 & 006 & 2036 & 0.39 & 71517 \\
\hline LV-MS & 103 & 0.05 & 100 & -0.06 & 0.08 & 1.1402 & 291396 & 0.10 & 2.645 & -0.19 & 73997 \\
\hline IV_LS & $s 1$ & 0.04 & 0.90 & .0 .28 & -0.04 & 1.1671 & 2.67551 & 0.08 & 2311 & .0 .94 & 5.6521 \\
\hline $\mathrm{Mv}_{3} \mathrm{ss}$ & 102 & 0.04 & 0.94 & 0.11 & 0.91 & 17235 & 3.64735 & 0.71 & 2873 & 1.02 & 11002 \\
\hline MN_NS & 204 & 0.07 & 101 & -0.04 & -0.34 & 1.8675 & 3.4575s & -0.38 & 2715 & -1.58 & 9.8685 \\
\hline MN IS & 101 & 0.04 & 0.96 & 0.10 & 0.21 & 20556 & 3.49184 & 0.19 & 2969 & .028 & 73996 \\
\hline $\mathrm{HV}_{-}^{-} \mathrm{SS}$ & 32 & -0.03 & 0.90 & 0.48 & 0.96 & 3.6609 & 5.62339 & 0.65 & 4.293 & -0.11 & 13362 \\
\hline $\mathrm{HV}_{-} \mathrm{MSS}$ & 105 & 0.05 & 2.04 & -0.63 & -0.58 & 3.8783 & 5.48209 & .029 & 3.697 & 0.95 & 14316 \\
\hline HV_LS & 33 & 0.08 & 105 & 0.27 & 0.34 & 4.0563 & 4.78283 & 0.16 & 3344 & 0.64 & 11344 \\
\hline \multicolumn{12}{|c|}{ PabelD. Newr } \\
\hline GN & 206 & 0.06 & 101 & 0.12 & 471 & 29654 & 401406 & 460 & 2045 & 420 & 11597 \\
\hline NN & 410 & 0.03 & 0.96 & -0.07 & -0.19 & 2.1048 & 236496 & -0.17 & 1269 & -0.60 & 3.5858 \\
\hline BN & 206 & 0.07 & 101 & 0.05 & -4.03 & $2 \mathrm{~mm}$ & 334578 & -4.15 & 1.784 & -4.03 & 11344 \\
\hline
\end{tabular}

Table 5: Summary Statistics for the 822 quarterly announcements (2)

\begin{tabular}{|c|c|c|c|c|c|c|c|c|c|c|c|}
\hline \\
\hline IV_GS & 39 & 008 & 102 & $-0,2$ & 430 & 11152 & 260134 & 439 & 2230 & 4.10 & 82326 \\
\hline LV_NN & 127 & 0.02 & 0.94 & .009 & .0 .22 & 1.1579 & 1.61993 & -0.15 & 1.196 & -0.46 & 6.6398 \\
\hline LV_EN & 39 & 0.09 & 0.98 & -0.08 & -3.76 & 12027 & 250315 & -3.79 & 1993 & -4.85 & 72659 \\
\hline MV_GN & 101 & 0.08 & 0.97 & 0.03 & 4.44 & 23907 & 3.13192 & 4.41 & 1.709 & 4.51 & 9.1145 \\
\hline MN_NN & 204 & 0.04 & 0.97 & 0.07 & -0.13 & 1.6286 & 213531 & -0.25 & 1.296 & -124 & 85760 \\
\hline MN_EN & 102 & 0.07 & 100 & -0.12 & -3.97 & 2.1847 & 3020286 & -3.91 & 1.487 & -4.05 & 11.838 \\
\hline $\mathrm{Hv}, \mathrm{GN}$ & 66 & 0.02 & 1.07 & 0.29 & 1.05 & 4.1429 & 5.60056 & 4.56 & $25 s 4$ & 3.58 & 15.709 \\
\hline $\mathrm{HV}_{-} \mathrm{NN}$ & 79 & 0.03 & 0.93 & -0.41 & .0 .28 & 3.7295 & 358501 & 0.00 & 1299 & 0.88 & 12099 \\
\hline HV_EN & 65 & 0.05 & 1.04 & 0.33 & -4.20 & 3.7692 & 4.02397 & -4.63 & 1.950 & -3.68 & 12.135 \\
\hline \multicolumn{12}{|c|}{ PavelF. Nerts ado Sire } \\
\hline GN3S & 66 & 0.02 & 093 & 0.69 & 5.15 & 32666 & 4.400354 & 4.65 & 2145 & 257 & 12453 \\
\hline $\mathrm{GN}-\mathrm{MS}$ & 59 & 0.09 & 108 & -0.09 & 4.66 & 25527 & 392962 & 4.62 & 2168 & 8.78 & 12765 \\
\hline GN_Ls & $s$ & 0.08 & 102 & -034 & 4.15 & 3.0367 & 3.57318 & 4.53 & 1.748 & 4.09 & 79697 \\
\hline $\mathrm{NN}_{-} \mathrm{ss}$ & 94 & 0.01 & 0.90 & -0.04 & -0.07 & 1.9857 & 227657 & -0.04 & 1.269 & -0.44 & 10285 \\
\hline NN_Ms & 212 & 0.04 & 0.99 & -0.18 & -0.28 & 2.1144 & 245093 & -0.21 & 1.279 & -0.66 & 8.8161 \\
\hline NN_Ls & 104 & 0.04 & 0.94 & 0.13 & -0.09 & 2.1875 & 226514 & -0.21 & $1.25 s$ & -0.63 & 7.6549 \\
\hline BN__Ss & 45 & 0.00 & 0.96 & 0.54 & -3.79 & 2.8485 & 3.23731 & -431 & 2325 & 0.53 & 13.197 \\
\hline $\mathrm{EN}_{-} \mathrm{NS}$ & $m$ & 0.11 & 1.04 & -0.21 & -4.23 & 28114 & 3.51056 & -4.20 & $1.7 m$ & -5.78 & 11.699 \\
\hline EN_LS & so & 0.04 & 1.00 & 0.18 & -3.79 & 2.6371 & 3.12848 & -3.90 & 1.113 & -430 & 6.8778 \\
\hline Toral & 322 & 0.04 & 095 & -0.01 & 0.10 & 2005 & 39653 & 0.07 & 3044 & -0.26 & 10.155 \\
\hline
\end{tabular}

Note: Sample Statistics are shown for 822 quarterly announcement events of NSE-50 stocks during the period of 2005-2010. Abnormal Return (AR) is calculated by using daily adjusted closing return of the Market Model (OLS). Estimation window is considered as 100 days. Cumulative Abnormal Return (CAR) is calculated by accumulating $\mathrm{AR}$ over the event windows $(-10,0,+10=21$ days $) . \mathrm{N}=$ sample

Dr.Sitangshu Khatua, Dr. Hemant Kumar Pradhan

P a g e $|7|$ Emerging Markets Journal 


\section{Results}

\section{Table 6: Results for individual size, volatility and asymmetry or news effect}

\begin{tabular}{|c|c|c|c|c|c|c|c|c|}
\hline \multicolumn{9}{|c|}{ Panel A: Size ( $\mathrm{N}=822)$} \\
\hline \multicolumn{2}{|c|}{$\begin{array}{l}\text { Dependent } \\
\text { Variable }\end{array}$} & LS & MS & SS & $\begin{array}{l}\text { DW- } \\
\text { stat }\end{array}$ & $\begin{array}{l}\text { Adj. } \\
\mathrm{R}^{2}\end{array}$ & F-stat & Prob(F) \\
\hline \multirow[t]{3}{*}{$\mathrm{CAR}_{\mathrm{i}}$} & Coefficient & .3009 & $\begin{array}{l}-.6747 \\
\end{array}$ & $-1.941^{* *}$ & 2.09 & .0023 & 1.6207 & .6377 \\
\hline & t-stat & -.4196 & -1.333 & -2.01 & & & & \\
\hline & $\mathrm{N}$ & 205 & 412 & 205 & & & & \\
\hline \multicolumn{9}{|c|}{ Panel B: Volatility $(\mathrm{N}=822)$} \\
\hline \multicolumn{2}{|c|}{$\begin{array}{l}\text { Dependant } \\
\text { Variable }\end{array}$} & $\mathrm{HV}$ & MV & LV & $\begin{array}{l}\text { DW- } \\
\text { stat }\end{array}$ & $\begin{array}{l}\text { Adj. } \\
\mathrm{R}^{2}\end{array}$ & F-stat & Prob(F) \\
\hline \multirow[t]{3}{*}{$\mathrm{CAR}_{\mathrm{i}}$} & Coefficient & .5817 & -.7878 & -.3751. & 2.09 & .0005 & 1.23 & .5910 \\
\hline & t-stat & .8216 & -1.549 & -.5235 & & & & \\
\hline & $\mathrm{N}$ & 205 & 407 & 210 & & & & \\
\hline \multicolumn{9}{|c|}{ Panel C: News (N =822) } \\
\hline \multirow{2}{*}{\multicolumn{2}{|c|}{$\begin{array}{l}\text { Dependant } \\
\text { Variable }\end{array}$}} & GN & NN & $\mathrm{BN}$ & DW & Adj. & F-stat & Prob(F) \\
\hline & & & & & & & & \\
\hline \multirow[t]{3}{*}{$\mathrm{CAR}_{\mathrm{i}}$} & Coefficient & $\begin{array}{l}3.6755 \\
* *\end{array}$ & -.7562 & $\begin{array}{l}-3.8672 \\
* *\end{array}$ & 2.11 & -0608 & $\begin{array}{l}27.58 \\
* *\end{array}$ & .0000 \\
\hline & t-stat & 5.303 & -1.539 & -5.3608 & & & & \\
\hline & $\mathrm{N}$ & 206 & 410 & 206 & & & & \\
\hline
\end{tabular}

High Volatility and Low Volatility events. HV: High Volatility, MV: Medium Volatility and LV: Low Volatility. Panel C represents the significant difference between Good News and Bad News events. GN: Good News, NN: No News and BN: Bad News. N= Sample Size.** Significant at size. All are statistically significant at 5 percent level.

Note: Cross Sectional mean Cumulative Abnormal Returns (CARs), using the Market Model is shown for 822 quarterly announcements over the event window. T-statistics are calculated by standardizing the abnormal returns on each day for each event and then aggregating the standardized abnormal returns over the event period (21 days: -10,0,+10) to find out CAR. Panel A represents the significant difference between large size and small size firms. LS: Large Size, MS: Medium Size and SS: Small Size. Panel B represents the significant difference between

Examining Overreaction in Indian Stock Market for Quarterly News 
The first question is for addressing the size effect. Small cap firms, being less observed and more exposed to abnormality, may have a higher chance of reacting to a certain event. Whereas the actions of large cap firms are better observed and more anticipated, and thus any event would not be much of a signaling response. Being a large firm, they can absorb any shock by themselves, which a small firm cannot. The same thing has been found in the test shown in Panel A of Table 5. The difference between the two populations has the predicted sign and is marginally statistically significant (p-value of $6.3 \%$ ). The result indicates that small cap firm has more impact than large cap firms. Small cap coefficient also shows statically significant in the case of measuring overreaction. The second question addressed by the study was based on the notion that firms overreaction varies with volatility. Based on the data, it was not possible to reject the null hypothesis. There was no statistically-significant difference between high and low volatility. The results are shown in Panel B of Table 5. The result indicates that comparatively high volatility firms have marginally more impact than low volatility. Third question i.e. the asymmetry or the news effect are shown in the Panel $C$ of the table 5 , which shows more significant difference ( F-stat- 27.58 and p -value $0 \%)$. It indicates that bad news has much more impact on overreaction than good news, which is more logical and similar to previous literature. Overreactions are both statistically significant for good news as well as bad news events.

Table 7: Regression result for volatility and size combined

\begin{tabular}{lllll}
\hline $\begin{array}{l}\text { Dependant } \\
\text { Variable }\end{array}$ & $\begin{array}{l}\text { Independent } \\
\text { Variables }\end{array}$ & $\mathbf{N}$ & Coefficient & t-stat \\
\hline CAR $_{\text {i }}$ & LV_SS & 51 & 0.4076 & 0.2315 \\
& LV_MS & 103 & -0.3226 & - \\
& & & & 0.3384 \\
& LV_LS & 51 & -0.9698 & - \\
& & & & 0.7005 \\
& MV_SS & 102 & 0.7253 & 0.6813 \\
& MV_MS & 204 & $-1.7016^{* *}$ & - \\
& & & & 2.3672 \\
& MV_LS & 101 & -0.3725 & - \\
& & & & 0.3805 \\
& HV_SS & 52 & $-2.2515^{* *}$ & - \\
& & & & 2.2163 \\
& HV_MS & 105 & 1.1583 & 1.082 \\
& HV_LS & 53 & 0.8805 & 0.5424 \\
& DW-stat: & 2.113 & Adj. R & 0.005 \\
& F-stat: & 0.938 & Prob(F): & 0.483 \\
\hline
\end{tabular}

Note: The table represents the multiple regression results of the combined effects of volatility and size on overreaction. The model is: CARi $=$ b00*LV_SS + b01*LV_MS + b02*LV_LS + b10*MV_SS + b11*MV_MS + b12*MV_LS + b20*HV_SS + b21*HV_MS + b22*HV_LS, Where, LV_SS $=$ Low Volatility*Small
Size. The other dummy variables are defined in a similar manner. N= Sample Size. ${ }^{* *}$ Significant at 5\% level

Other regressions results appear in table 6,7 and 8. Table 6 represents the multiplication or joint effects of volatility and size. The highest volatility and smallest size dummy shows a marginally significant result $(-2.25$ at $5 \%$ significance level). Medium volatility and medium size is also shows statistically significant result. The cross product of volatility and news shown in the table 7 is that the abnormality in return increases with volatility and it further increases for the bad news. Hence market reacts more badly on negative news in an uncertain period. High-volatile and bad news dummy is statistically significant (-2.955 at 5\% level of significance). All the independent cross dummies of volatility and news are statistically significant except the no-news cases. Overall p-value of $0 \%$ and F-stat (7.271) also shows that joint effects of volatility and news have statistically significant impact on market overreactions.

Table 8: Regression result for volatility and news combined

\begin{tabular}{|c|c|c|c|c|}
\hline $\begin{array}{l}\text { Dependa } \\
\text { nt } \\
\text { Variable }\end{array}$ & $\begin{array}{l}\text { Independe } \\
\text { nt } \\
\text { Variables }\end{array}$ & $\mathbf{N}$ & $\begin{array}{l}\text { Coefficie } \\
\text { nt }\end{array}$ & t-stat \\
\hline \multirow{11}{*}{$\mathrm{CAR}_{\mathrm{i}}$} & LV_GN & 39 & $3.738 * *$ & 2.342 \\
\hline & LV_NN & 127 & -0.3787 & $-\overline{0.4283}$ \\
\hline & LV_BN & 39 & $-4.4769 * *$ & $\begin{array}{l}- \\
2.8059\end{array}$ \\
\hline & MV_GN & 101 & $3.2424 * *$ & 3.2704 \\
\hline & MV_NN & 204 & -1.432 & $\begin{array}{l}- \\
2.0541 \\
5\end{array}$ \\
\hline & MV_BN & 102 & $-3.4883 * *$ & $-\overline{3.5358}$ \\
\hline & HV_GN & 66 & $4.3013^{* *}$ & 3.5071 \\
\hline & HV_NN & 79 & 0.3843 & 0.3428 \\
\hline & HV_BN & 65 & $-2.955^{* *}$ & $\begin{array}{l}- \\
2.3911\end{array}$ \\
\hline & DW-stat: & 2.115 & Adj. $\mathrm{R}^{2:}$ & 0.0575 \\
\hline & F-stat: & $\begin{array}{l}7.271 * \\
*\end{array}$ & Prob(F): & $\underline{0.0000}$ \\
\hline
\end{tabular}

Note: The table represents the multiple regression results of the combined effects of volatility and news on overreaction. The model is: CARi $=$ b00*LV_GN + b01*LV_NN + b02*LV_BN + b10*MV_GN + b11*MV_NN + b12*MV_BN + b20*HV_GN + b21*HV_NN+ b22*HV_BN, Where, LV_GN= Low Volatility*Good News. The other dummy variables are defined in a similar manner. $\mathrm{N}=$ Sample Size. ${ }^{* *}$ Significant at $5 \%$ level

The cross product of news and size shown in the table 8 is that the abnormality in return is more for bad news as well as good news. Hence market reacts more badly on any extreme price changes. Cross dummies associated with medium size are shown more statistically significant results than others. All the independent cross 
dummies of news and size are statistically significant except the no-news cases. Overall p-value of $0 \%$ and F-stat (7.416) also shows that joint effects of news and size have statistically significant impact on market overreactions.

Table 9: Regression result for news and size combined

\begin{tabular}{lllll}
\hline $\begin{array}{l}\text { Dependant } \\
\text { Variable }\end{array}$ & $\begin{array}{l}\text { Independent } \\
\text { Variables }\end{array}$ & N & Coefficient & t-stat \\
\hline CAR $_{\mathrm{i}}$ & GN_SS & 66 & $2.624^{* *}$ & 2.1416 \\
& GN_MS & 89 & $4.558^{* *}$ & 4.3194 \\
& GN_LS & 51 & $3.493^{* *}$ & 2.5057 \\
& NN_SS & 94 & -0.3760 & - \\
& NN_MS & 212 & -0.8879 & -1.298 \\
& NN_LS & 104 & -0.8314 & - \\
& & & & 0.8515 \\
& BN_SS & 45 & $-2.693^{* *}$ & - \\
& BN_MS & 111 & $-4.4638^{* *}$ & - \\
& & & & 4.1406 \\
& BN_LS & 50 & $-3.0162^{* *}$ & - \\
& & & & 2.1419 \\
& DW-stat: & 2.106 & Adj. R & 0.0588 \\
& F-stat: & $7.416^{* *}$ & Prob(F): & $\mathbf{0 . 0 0 0 0}$ \\
\hline
\end{tabular}

Note: The table represents the multiple regression results of the combined effects of news and size on overreaction. The model is: $\mathrm{CARi}=$ b00*GN_SS + b01*GN_MS + b02* GN_LS + b10* NN_SS + b11*NN_MS + b12* NN_LS + b20* BN_SS + b21* BN_MS + b22* BN_LS, Where, GN_SS $=$ Good News $*$ Small Size. The other dummy variables are defined in a similar manner. $\mathrm{N}=$ Sample Size.** Significant at 5\% level

\section{Robustness Considerations}

In order to check whether the results are stable over time the CARs of events have been re-examined for the two approximately equal-size sub periods within the sample period. During the study period, year 2008 is considered as the year of separation to check the effect of pre and post global crisis period. In this way, the sub periods ( From Oct'05 to Jun'08 and from Jul'08 to Nov'10) are selected in such a way so that the sample period is almost split in half in chronological order. CARs are found statistically significant for the two sample periods. In the first period sample size is 352 and in the later one it is 470 events. Overall, the results of the sub period analysis do not display any significant difference with the findings of the total periods. Thus it can be concluded that the actual findings seems to be stable over time and do not appear as sampleperiod dependent (Spyros,2007). As regression results are stable over time, it can be said that there are not any serious multi-colinearity issues. Further, everywhere DW statistics reaches at least a level of 2 . Hence it can be considered that the regression results are to be robust and any serious level of auto-correlation exists here. Levene Statistics value of $\mathrm{CAR}_{\mathrm{i}}$ is 3.547 for $1 \%$ significance level. This also considers one of the good results for showing homogeneity of the sample.

\section{Intra-Industry News Diffusion in the case of Quarterly Releases}

Before any announcements investors can make an idea from news provided by various public channels. One important source is intra-industry firms' earnings reports (Foster,1981; Freeman and Tse, 1992). Givoly and Palmon (1982) find that late-announcers have reduced stock-price over-reactions, because investors are already prepared about the earnings from early peer announcements.

Prior research has documented that earnings announcements provide information not only about the announcing firm but also about other firms in the same industry ( Thomas and Zhang, 2008; Griffin and Hirschey, 2011). It can be studied that how stock market overreaction associated with the phenomenon of intra-industry information transfers. How the stock price movements of late announcers in response to earnings reported by early announcers are related to subsequent price responses of late announcers to their own earnings reports. Apparently, the stock market overestimates the intra-industry implications of early announcers' earnings for late announcers' earnings, and that overestimation is corrected when late announcers disclose their earnings.

\subsection{Methods}

The reason behind the overreaction may be due to investors' incapability to realize entirely the positive correlation in earnings announcement by industry peers (Ramnath, 2002). This explanation is consistent with bias caused by investors depending on the representativeness heuristic discussed in behavioral finance ( Barberis et al., 1998; Chan et al., 2004). Stock-price of late announcing firm adjusts through a couple of price changes those are more-or-less positively related. This leads the lateannouncer's price to overshoot the price which reflects the earning news it ultimately releases.

It has been also considered the findings of Bernard and Thomas (1990) that are based on investors not understanding the extent to which news in earnings this quarter spills over to future quarter earnings. This study is based on earnings information containing of two parts. One component that has spillover effects for upcoming quarters and a second part that does not. Intra-industry information transfers from early announcers to late 
announcers consisting mainly of the second component, which does not have impact for adjacent quarters. It is felt that considerable progress remains to be made along this dimension.

Hypothesis H10: There is significant relation between stock price movements of late announcers during it's earning release period with respect to earnings reports by early peer announcers.

\subsection{Variables}

During the quarter earning disclosure period, the last announced firm is considered as the late announcing overreacted firm \& the others are early announcer peer firms within the same industry.

For each late-announcing firm $i$, we measure two sets of cumulative abnormal returns, one for firm $i$ and one for its peers. Each set contains two returns, one in response to that firm's own earnings announcement and one in response to the other firm's earnings announcement. All CARs are computed as per the market model and the threeday windows cover the $(1,1)$ period, where day 0 is the earnings announcement date.

$\mathbf{1 . C A R}_{\mathbf{i t}}=$ cumulative abnormal returns for late announcing firm $i$ around its own earnings announcement date $t$ ($1,0,+1)$

2.RESPONSE $\mathbf{E}_{\mathbf{i T}}=$ average cumulative abnormal returns of the firm i over a similar three-day window around the announcement of peer firms in the industry that have already announced during their announcement date $\mathrm{T}$ ($1,0,+1)$

To ensure that above two periods do not overlap it is required that the peer's earnings announcement date precede firm i's earnings announcement date by at least five calendar days or one week. Since there is typically more than one peer firm that announces its earnings earlier, the mean of those peers' announcements is used to measure firm i's response to industry peers' earnings announcements. During the announcement period, the maximum time gap between the earliest peer firm's announcement date and the late announcing firm's date is one month to remove confounding effect.

Turning to the second set of returns-for peer firms - we measure similar event returns on the same two dates for those peers that announce earnings before firm $i$. That is, we calculate the returns over three-day windows for each of these peers at their own earnings announcement dates and at the earnings announcement date for the lateannouncing firm $i$.

3.PRCAR $\mathbf{P}_{\mathbf{i t}}=$ the averages of CARs across all eligible peers during their own announcement date

4.PRRESPONSE $\mathrm{iT}_{\mathrm{T}}=$ early peers' response to the earnings announcement for firm i i.e. average CARs of peer firms during the firm i's announcement date to illustrate how we measure all the four variables consider the following example (see figure below). Assume that an industry has four firms ( W, X, Y, Z and i) that announce their last quarter earnings on May 27, April 15, 18, 24, and 27, respectively. Firm i's early-announcing peers include firms $\mathrm{X}$ and $\mathrm{Y}$ but not firm $\mathrm{Z}$ and $\mathrm{W}$.

Some additional variables we consider for control purposes are as follows:

1.PEER $_{\mathbf{n}}=$ the number of early peers that announce earnings at least five days prior to firm i's announcement date.

2.LAGTIME = the average time lag between the announcement dates for early peer firms and the announcement date for firm i.

3.CAR $\mathbf{R}_{\mathbf{t}-\mathbf{1}}=$ Firm i 's three-day earnings announcement cumulative abnormal returns around the earnings announcement date in previous quarter $(\mathrm{t}-1)$

4. $\mathbf{C A R}_{\mathbf{t}-4}=$ Firm i 's three-day earnings announcement cumulative abnormal returns around the earnings announcement date during the same quarter in the previous fiscal year $(\mathrm{t}-4)$

5.Size $_{\mathrm{i}}=$ Market cap of firm i around its own earning announcement date

6.Return $_{6 \mathrm{~m}}=$ Firm i's last 6 months returns 1 week prior to the announcement date

\subsection{Results}

Table 9 provides descriptive statistics for the variables of interest. As shown in panel $A$, the mean earnings announcement return $\mathrm{CAR}_{\mathrm{it}}$ is close to zero, in contrast to a positive mean return documented in the literature (Ball and Kothari,1991). The average RESPONSE $\mathrm{iT}_{\mathrm{iT}}$ of $0.503 \%$ reported in panel A suggests that early announcers tend to have higher announcement returns than late announcers (Givoly and Palmon ,1982).

Table 9, panel B provides Pearson and Spearman correlations among the different variables. There can be six possible correlations among $\mathrm{CAR}_{\mathrm{it}}$, RESPONSE $\mathrm{E}_{\mathrm{iT},} \mathrm{PRCAR}_{\mathrm{it}}$ and PRRESPONSE $\mathrm{E}_{\mathrm{iT}}$ covering the announcement returns and responses to peers' announcements. Out of which, the correlation between $\mathrm{CAR}_{\mathrm{it}}$ and RESPONSE $\mathrm{E}_{\mathrm{iT}}$ is negative only. This conveys that the stock price of a late announcer firm over-reacts to the news transferred from the earnings disclosure by the early peers. But it is afterward corrected during the announcement of the late announcer firm's own earnings. The positive correlations between $\mathrm{CAR}_{\text {it }}$ and PRRESPONSE $_{\mathrm{iT}}$, and PRCAR it and RESPONSE iT signifies intra-industry information transfers. The positive correlation between $\mathrm{CAR}_{\text {it }}$ and $\mathrm{PRCAR}_{\text {it }}$ is also consistent with the lead-lag effect from large to small firms in earlier literature (Hou, 2007), as early announcers tend to be larger firms. Interestingly, RESPONSE $\mathrm{iT}_{\mathrm{T}}$, and $\mathrm{PRCAR}_{\mathrm{it}}$ are 
positively correlated with each other, but $\mathrm{CAR}_{\text {it }}$ is positively related with the earlier and negatively with the later. This evidence documents consistent news dissemination from announcement of the peer-group. The positive correlation between $\mathrm{CAR}_{\mathrm{t}-1}$ and $\operatorname{Return}_{6 \mathrm{~m}}$ with $\mathrm{CAR}_{\mathrm{it}}$ and $\mathrm{CAR}_{\mathrm{t}-1}$ and Return $_{6 \mathrm{~m}}$ with RESPONSE $\mathrm{ET}_{\mathrm{T}}$ respectively confirms the presence of momentum or ownfirm under-reaction also.

Table 10 indicates substantial proof of price reversal. RESPONSE $_{\mathrm{iT}}$ increases from $-4.98 \%$ in D1 to $8.39 \%$ in D2 whereas $\mathrm{CAR}_{\mathrm{it}}$ depicts a steady decrease from $0.81 \%$ in $\mathrm{D} 1$ to $-0.32 \%$ in D10. A hedge portfolio (D1-D10) with a long position in D1 stocks and a short position in D10 stocks yields a three-day market excess return of $1.13 \%$, with a $t$ statistic of 9.36 .

Table 11 documents the regression results of $\mathrm{CAR}_{\mathrm{it}}$, and RESPONSE $_{i \mathrm{~T}}$ in the presence of control variables like PRCAR $_{\mathrm{it}}, \quad$ PRRESPONSE $_{\mathrm{iT}}, \quad \mathrm{CAR}_{\mathrm{t}-1}, \mathrm{CAR}_{\mathrm{t}-4}$,Size, Return $_{6 \mathrm{~m}}$, LAGTIME and PEER $\mathrm{P}_{\mathrm{n}}$. As various combination of control variables are introduced in the model I to $\mathrm{V}$, the values of coefficient on RESPONSE $\mathrm{i}_{\mathrm{iT}}$ and corresponding tstatistics are not very much different. Overall, opposite relation between $\mathrm{CAR}_{\mathrm{it}}$ and RESPONSE $\mathrm{i}_{\mathrm{iT}}$ appears uniformly under different background.

The analysis reported in model VI is designed to investigate whether the degree of overreaction differs across observations depending on the consistency between the news revealed by the early announcer and the implications of that news for the late announcer.

A dummy variable, $D$, is used here. It is set to one when RESPONSE $\mathrm{E}_{\mathrm{iT}}$ and $\mathrm{PRCAR}_{\mathrm{it}}$ are of the same sign and zero otherwise. It confers that the positive news reported by the early announcer signifies positive news for the late announcer also and vice versa. The table 11 also provides a negative and significant coefficient on D*RESPONSE. It evidences more overreaction to information transfers when there is more information transfer.

$\mathbf{C A R}_{\text {it }}=$ cumulative abnormal returns for late announcing firm $i$ around its own earnings announcement date t ($1,0,+1)$

RESPONSE $_{\mathbf{i T}}=$ average cumulative abnormal returns of the firm i over a similar three-day window around the announcement of peer firms in the industry that have already announced during their announcement date $\mathrm{T}$ ($1,0,+1)$

PRCAR $_{\mathbf{i t}}=$ the averages of CARs across all eligible peers during their own announcement date
PRRESPONSE $_{\mathbf{i T}}=$ early peers' response to the earnings announcement for firm i i.e average CARs of peer firms during the firm i's announcement date

$\mathbf{P E E R}_{\mathbf{n}}=$ the number of early peers that announce earnings at least five days prior to firm i's announcement date.

LAGTIME = the average time lag between the announcement dates for early peer firms and the announcement date for firm i.

$\mathbf{C A R}_{\mathbf{t}-\mathbf{1}}=$ Firm i 's three-day earnings announcement cumulative abnormal returns around the earnings announcement date in previous quarter $(\mathrm{t}-1)$

$\mathbf{C A R}_{\mathbf{t}-\mathbf{4}}=$ Firm i 's three-day earnings announcement cumulative abnormal returns around the earnings announcement date during the same quarter in the previous fiscal year $(\mathrm{t}-4)$

Size $_{\mathrm{i}}=$ Market cap of firm $\mathrm{i}$ around its own earning announcement date

Return $_{6 m}=$ Firm i's last 6 months returns 1 week prior to the announcement date 
Table 10. Descriptive Statistics

\begin{tabular}{|l|l|l|l|l|l|l|}
\hline \multicolumn{6}{|l|}{ Panel A: Descriptive Statistics } \\
\hline Variable & N & Mean & SD & SE & Max & Min \\
\hline CAR $_{\text {it }}$ & 1956 & $0.021 \%$ & $9.98 \%$ & 0.004 & $43.45 \%$ & $-35.56 \%$ \\
\hline RESPONSE $_{\text {iT }}$ & 1897 & $0.503 \%$ & $4.01 \%$ & 0.1254 & $25.41 \%$ & $-29.45 \%$ \\
\hline PRCAR $_{\text {it }}$ & 1956 & $0.075 \%$ & $5.89 \%$ & 0.0127 & $33.78 \%$ & $-21.59 \%$ \\
\hline PRRESPONSE $_{\text {iT }}$ & 1897 & $0.038 \%$ & $3.23 \%$ & 0.0117 & $27.53 \%$ & $-19.78 \%$ \\
\hline CAR $_{\mathbf{t}-1}$ & 1863 & $0.058 \%$ & $8.89 \%$ & 0.0065 & $40.01 \%$ & $-34.56 \%$ \\
\hline CAR $_{\mathbf{t}-4}$ & 1759 & $0.051 \%$ & $7.76 \%$ & 0.0065 & $41.35 \%$ & $-30.09 \%$ \\
\hline Size $_{i}$ & 1956 & 40,350 & 63,756 & 0.6329 & $3,65,331$ & 561 \\
\hline Return $_{6 m}$ & 1956 & 0.043 & $0.891 \%$ & 0.0483 & $9.675 \%$ & $-0.078 \%$ \\
\hline PEER $_{\mathbf{n}}$ & 1956 & 5.67 & 11.31 & 0.5013 & 11 & 1 \\
\hline LAGTIME & 1956 & 12.42 & 8.67 & 1.4325 & 39 & 5 \\
\hline
\end{tabular}

(continued)

\section{Table 11. Descriptive Statistics (2)}

\begin{tabular}{|c|c|c|c|c|c|c|c|c|}
\hline \multicolumn{9}{|c|}{ Panel B: Correlation Matrix } \\
\hline Variable & $\begin{array}{l}\mathrm{CAR}_{\mathrm{i}} \\
\mathrm{t}\end{array}$ & $\begin{array}{l}\text { RESPON } \\
S_{\text {iT }}\end{array}$ & $\begin{array}{l}\text { PRC } \\
\text { AR }_{\text {it }}\end{array}$ & $\begin{array}{l}\text { PRRESP } \\
\text { ONSE }_{\text {iT }}\end{array}$ & $\mathrm{CARR}_{t-1}$ & $\begin{array}{l}\mathbf{C A R}_{\mathbf{t}} \\
-4\end{array}$ & Size $_{i}$ & $\begin{array}{l}\text { Return } \\
6 \mathrm{~m}\end{array}$ \\
\hline $\mathrm{CAR}_{\text {it }}$ & 1 & -0.057 & 0.023 & 0.121 & 0.037 & 0.029 & 0.005 & 0.017 \\
\hline $\begin{array}{l}\text { RESPONSE } \\
\text { iт }\end{array}$ & $\begin{array}{l}- \\
0.051\end{array}$ & 1 & 0.125 & 0.006 & 0.023 & 0.008 & -0.003 & 0.111 \\
\hline PRCAR $_{\text {it }}$ & 0.019 & 0.157 & 1 & 0.017 & 0.003 & 0.003 & 0.007 & 0.025 \\
\hline $\begin{array}{l}\text { PRRESPO } \\
\text { NSE }_{\text {iT }}\end{array}$ & 0.189 & 0.007 & 0.015 & 1 & -0.009 & 0.007 & 0.004 & 0.009 \\
\hline $\mathrm{CAR}_{t-1}$ & 0.035 & 0.021 & 0.002 & -0.008 & 1 & 0.006 & 0.003 & 0.212 \\
\hline $\mathbf{C A R}_{t-4}$ & 0.023 & 0.009 & 0.003 & 0.007 & 0.006 & 1 & 0.003 & 0.006 \\
\hline Size $_{\mathbf{i}}$ & 0.007 & -0.004 & 0.008 & 0.003 & 0.004 & 0.002 & 1 & -0.018 \\
\hline Return $_{6 m}$ & 0.019 & 0.101 & 0.027 & 0.008 & 0.196 & 0.005 & -0.019 & 1 \\
\hline
\end{tabular}

Note: Pearson correlations are shown above the diagonal and Spearman correlations are shown below the diagonal. The sample includes BSE-100 stocks during the period of Oct'05 to Nov'10 ( 22 quarters) with non-missing quarterly announcements returns from firm $\mathrm{i}$ and its early peers. There are 1956 firmannouncements with available data. All variables are statistically significant at $5 \%$ level of significance except $\mathrm{PEER}_{\mathrm{n}}$ and LAGTIME. Variables are as follows: 
Table 12. Deciles Based Ranking on Firm i's over reaction (CAR) to Early Peers' Earnings Announcements (RESPONSE)

\begin{tabular}{|l|l|l|l|l|}
\hline & $\begin{array}{l}\text { RESPO } \\
\text { NSE (\%) }\end{array}$ & $\begin{array}{l}\text { CAR } \\
(\%)\end{array}$ & $\begin{array}{l}\text { PRRESPO } \\
\text { NSE (\%) }\end{array}$ & $\begin{array}{l}\text { PRCAR } \\
(\%)\end{array}$ \\
\hline $\begin{array}{l}\mathrm{D}_{1} \\
\text { (low) }\end{array}$ & -4.98 & 0.81 & -0.03 & -0.09 \\
\hline $\mathrm{D}_{2}$ & -3.34 & 0.67 & -0.01 & -0.01 \\
\hline $\mathrm{D}_{3}$ & -2.98 & 0.78 & 0.04 & 0.03 \\
\hline $\mathrm{D}_{4}$ & -1.92 & 0.34 & 0.07 & 0.13 \\
\hline $\mathrm{D}_{5}$ & -0.67 & 0.22 & 0.02 & 0.54 \\
\hline $\mathrm{D}_{6}$ & 0.156 & 0.19 & 0.06 & 0.68 \\
\hline $\mathrm{D}_{7}$ & 1.89 & 0.07 & 0.09 & 0.89 \\
\hline $\mathrm{D}_{8}$ & 3.98 & -0.12 & 0.08 & 0.97 \\
\hline $\mathrm{D}_{9}$ & 6.67 & -0.29 & 0.03 & 1.01 \\
\hline $\begin{array}{l}\mathrm{D}_{10} \\
(\text { high })\end{array}$ & 8.39 & -0.32 & -0.02 & 1.37 \\
\hline $\mathrm{D}_{1}-\mathrm{D}_{10}$ & -13.37 & 1.13 & -0.01 & -1.46 \\
\hline (t-stat) & $(37.67)$ & $(9.36)$ & $(0.876)$ & $(-15.34)$ \\
\hline
\end{tabular}

Note: $\mathbf{C A R}_{\mathbf{i t}}=$ cumulative abnormal returns for late announcing firm $i$ around its own earnings announcement date $\mathrm{t}(-1,0,+1)$; RESPONSE $_{\mathrm{iT}}=$ average cumulative abnormal returns of the firm $\mathrm{i}$ over a similar three-day window around the announcement of peer firms in the industry that have already announced during their announcement date $\mathrm{T}$ $(-1,0,+1) ;$ PRCAR $_{\mathbf{i t}}=$ the averages of CARs across all eligible peers during their own announcement date; PRRESPONSE $_{\mathrm{iT}}=$ early peers' response to the earnings announcement for firm i i.e average CARs of peer firms during the firm i's announcement date. Firms are first sorted into 10 deciles for each quarter based on RESPONSE iT $_{\mathbf{T}}$, then mean values for firms in each deciles are calculated and finally maximum one across 22 quarters ( Oct'05 - Nov'10) is taken for each decile. There are 1956 firm-announcements with available data for 100 firms. All variables are statistically significant at $5 \%$ level of significance except $\mathbf{C A R} \mathbf{R}_{\mathbf{i t}}$. Portfolios with fewer than 5 stocks are eliminated.
Table 13. Regression results of CAR on RESPONSE \& Other Control Variable

\begin{tabular}{|c|c|c|c|c|c|c|}
\hline & Model I & $\begin{array}{l}\text { Model } \\
\text { II }\end{array}$ & $\begin{array}{l}\text { Model } \\
\text { III }\end{array}$ & $\begin{array}{l}\text { Model } \\
\text { IV }\end{array}$ & $\begin{array}{l}\text { Model } \\
\text { V }\end{array}$ & $\begin{array}{l}\text { Model } \\
\text { VI\# }\end{array}$ \\
\hline Intercept & $\begin{array}{l}0.00 \\
(0.98)\end{array}$ & $\begin{array}{l}0.00 \\
(0.44)\end{array}$ & $\begin{array}{l}0.00 \\
(0.87)\end{array}$ & $\begin{array}{l}0.00 \\
(0.32)\end{array}$ & $\begin{array}{l}0.00 \\
(0.29)\end{array}$ & $\begin{array}{l}0.00 \\
(0.23)\end{array}$ \\
\hline $\begin{array}{l}\text { RESPON } \\
\text { SE }\end{array}$ & $\begin{array}{l}-0.098 * * \\
(-15.34)\end{array}$ & $\begin{array}{l}- \\
0.035 * * \\
(-10.23)\end{array}$ & $\begin{array}{l}- \\
0.079 * * \\
(-11.89)\end{array}$ & $\begin{array}{l}- \\
0.121^{* *} \\
(-12.64)\end{array}$ & $\begin{array}{l}- \\
0.234^{* *} \\
(-13.39)\end{array}$ & $\begin{array}{l}- \\
0.1345^{*} \\
* \\
(-15.67)\end{array}$ \\
\hline D & & & & & & $\begin{array}{l}-0.00 \\
(-0.976)\end{array}$ \\
\hline $\begin{array}{l}\text { D*RESP } \\
\text { ONSE }\end{array}$ & & & & & & $\begin{array}{l}- \\
0.039 * * \\
(-2.56)\end{array}$ \\
\hline $\begin{array}{l}\text { PRRESP } \\
\text { ONSE }\end{array}$ & & & $\begin{array}{l}0.078 \\
(1.21)\end{array}$ & $\begin{array}{l}0.045 \\
(0.786)\end{array}$ & $\begin{array}{l}0.0236 * \\
* \\
(3.31)\end{array}$ & $\begin{array}{l}0.076^{* *} \\
(3.45)\end{array}$ \\
\hline PRCAR & & & & $\begin{array}{l}0.032^{* * *} \\
(4.67)\end{array}$ & $\begin{array}{l}0.054^{* *} \\
(3.29)\end{array}$ & $\begin{array}{l}0.039 * * \\
(3.71)\end{array}$ \\
\hline$\overline{A R_{t-1}}$ & & $\begin{array}{l}0.047 * 8 \\
(9.98)\end{array}$ & & & $\begin{array}{l}0.087^{* *} \\
(12.32)\end{array}$ & $\begin{array}{l}0.092^{* *} \\
(12.98)\end{array}$ \\
\hline$\overline{\mathbf{A R}_{\mathrm{t}-4}}$ & & $\begin{array}{l}-0.008 \\
(-0.987)\end{array}$ & & & $\begin{array}{l}-0.007^{*} \\
(-2.32)\end{array}$ & $\begin{array}{l}0.003 \\
(0.987)\end{array}$ \\
\hline SIZE & & $\begin{array}{l}0.01 \\
(0.26) \\
\end{array}$ & & & $\begin{array}{l}0.006 \\
(0.975) \\
\end{array}$ & $\begin{array}{l}0.009 \\
(1.023) \\
\end{array}$ \\
\hline Return $_{6 m}$ & & $\begin{array}{l}0.009^{*} \\
(2.78)\end{array}$ & & & $\begin{array}{l}0.002 \\
(1.023)\end{array}$ & $\begin{array}{l}0.003 \\
(1.08)\end{array}$ \\
\hline $\begin{array}{l}\text { LAGTIM } \\
\text { E }\end{array}$ & & $\begin{array}{l}0.00 \\
(0.987)\end{array}$ & & & & \\
\hline PEER $_{n}$ & & $\begin{array}{l}0.007 \\
(0.765)\end{array}$ & & & & \\
\hline$\overline{A d j} R^{2}$ & 0.004 & 0.015 & 0.012 & 0.009 & 0.013 & 0.012 \\
\hline
\end{tabular}

Note: This table reports the mean coefficient estimates across regressions of $\mathbf{A R}_{\mathbf{i t}}$ on RESPONSE and other variables as defined earlier. There are 1956 firmannouncements with available data for 100 firms. **: Variables are statistically significant at 5\% level of significance. t-statistics are given within parentheses. See table 5.12 for detailed definitions. \# D = dummy variable for consistency of information transfer news. $\mathrm{D}$ is a dummy variable set equal to 1 if $R E S P$ *ERLYPRARET $>0$, and 0 otherwise; i.e., $D=1$ if the early announcer's news and the late announcer's response are consistent.

\section{Concluding Remarks}

In this study, the market over reaction has been investigated during the quarterly earnings announcements. While excess stock returns around this event have already been evidenced for a couple of years, the present study also finds out that these excess stock returns change depending on the level of market volatility. It has also been evidenced that positive CARs around the event are caused by periods of high volatility and are more significant for small firms. These events are also tested across the extent of 
information content of that news. That is why, events are categorized as good news, bad news and no news depending on the extent of variation from actual and expected return. The present study finds that market overreacts more on any bad news than in any good news. It proves the information asymmetry.

The outcome of this study may help to evaluate the extent of informational content of quarterly announcements, and whether the investors are affected by the various signals. It may so happen that market-players act differently to earning announcements during different market volatility conditions of various firms of various sizes in different firm-specific news- good, bad or no news. It may also explain the nature of reaction for the case of small vs. large firms in the most advantageous manner. The present study also substantiates the policy recommendation for the market players as well as for the analysts in estimating quarterly announcement events under different market condition and different market capitalization value of the firm.

The event study mechanism is only applied on mostly traded stocks in stock market and listed firms. That is why, NSE 50 stocks are chosen for experiment. But generally they are all large or medium size firms. Actual small size firms in the samples are not taken into consideration because of the above mentioned reason. This is the major limitation of the study. Overlapping of event windows or confounding effects are eliminated to some extent by using adjusted daily closing price and market model. Adjustment for other major stock-specific events like split, dividend and bonus etc. are already taken care of in adjusted closing price of the stock. When Market Model is used for estimated return, impact of any event related to the market is also eliminated. But still further scope of research is there to explore more on how to evaluate the impact of an event during a period after eliminating the effects of any other events either in the firm or in the national and international market. Specially, in this era of globalized open economy there is need of evolving a sophisticated statistical tool for measuring the impact of specified news at a given time by eliminating effects of other news during that particular time. This study can be further explored after making portfolio of various instead of individual stock. In Indian stock market presence of noninstitutional investors is more likely to cause noise in pricing mechanism, which may result in higher frequency of stock price correction. There are further scopes to study the impact of the noises.

Earlier research has acknowledged that quarterly reports endow with news not only about the announcing firm but also about peer-group firms in the same industry. The evidence of intra-industry information transfers has reported which is associated with stock market return anomaly. It is observed that the stock price movements of late announcers with respect to earnings reported by early announcers are negatively related to succeeding price reactions of late announcers to their own quarterly results. In fact the stock market overestimates the impact of intraindustry impact of early announcers' earnings for late announcers' earnings, and that overestimation is corrected when late announcers report their own earnings.

The outcome of this study gives an indication to the analyst, broker, investor, trader, speculator about the future actions. If a stock held for long experiences large positive return, holding of such should reduced by shorting the stock or buying put option and vice versa. Finding of this study encompasses strong implications for investor analysts, mutual fund managers as well as small investors who are continually engaged in designing a trading strategy.

As mentioned in the introduction of this study, this research was initiated to contribute to the existing literature on Overreaction and Event Study, to offer insights to the traders and institutional investors and to provide macro level inputs to the policy makers. Within the limitation, it is expected that the target has been achieved to a reasonable extent. However, that there are other explanations also and encourage future research to construct over and above what has been build up in the present study.

\section{REFERENCES}

Atiase, R. K., 1985. Pre-disclosure Information, Firm Capitalization, and Security Price Behavior around Earnings Announcement. Journal of Accounting Research. 23, 21-36.

Ball, R., Brown, P., 1968. An empirical evolution of accounting Income Numbers. Journal of Accounting Research. 6(2), 159-178.

Ball, R., Kothari, S.P., 1991. Security Returns around Earnings Announcements. The Accounting Review. 66(4), 718-738.

Barberis, N., Shleifer, A., Vishny, R.W., 1998. A Model of Investor Sentiment. Journal of Financial Economics. 49, 307-343.

Beneish, M. D., Whaley, R. E., 1996. An Anatomy of the "S\&P Game":The Effects of Changing the Rules. The Journal of Finance. 51(5), 1909-1930.

Bernard, V.L., Thomas, J.K., 1990. Evidence That Stock Markets Do Not Fully Reflect The Implications Of Current Earnings For Future Earnings. Journal of Accounting Economics.13, 305-340.

Boyd, J. H., Hu, J., Jagannathan,R., 2001. The stock market's reaction to unemployment news: Why bad news is usually good for stocks? Working paper, University of Minnesota, Minneapolis. 
Chan, W. S., Frankel, R., Kothari, S.P., 2004. Testing Behavioral Finance Theories Using Trends and Consistency in Financial Performance. Journal of Accounting and Economics. 38, 3-50.

Da Costa, N. Jr.,1994. Overreaction in the Brazilian stock market. Journal of Banking and Finance.19, 633-642.

DeAngelo, H., DeAngelo, L., Rice, E., 1984. Going private: Minority freeze out and stock holders wealth. Journal of Law and Economics. 27(2), 367-401.

De Bondt, W., Thaler, R., 1985. Does the Stock Market Overact? Journal of Finance. 40, 793-808.

Docking, D.S., Koch, P. D., 2005. Sensitivity of investor reaction to market direction and volatility: Dividend change announcement. The Journal of Financial Research, 28(1), 21-40.

Fama, E., Fisher, L., Jensen, M. C., Roll, R., 1969. The Adjustment of Stock prices to New Information. International Economic Review.10(1), 1-21.

Foster, G., 1981. Intra-industry information transfers associated with earnings releases. Journal of Accounting and Economics. 3, 201-232.

Freeman, R., 1987. The Association between Accounting Earnings and Security Returns for Large and Small Firms. Journal of Accounting and Economics. 9, 195-222.

Freeman, R., Tse, S., 1992. An earnings prediction approach to examining intercompany information transfers. Journal of Accounting and Economics. 15, 509-523.

Grant, E. B., 1980. Market Implications of Differential Amounts of Interim Information. Journal of Accounting Research.19, 255-268.

Givoly,D., Palmon,D., 1982. Timeliness of annual earnings announcements: some empirical evidence. Accounting Review. 57, 486-508.

Griffin, J., Hirschey, N., Kelly, P., 2011. How important is the financial media in global markets? The review of Financial Studies. 24(12), 3941-3992.

Hou, K., 2007. Industry Information Diffusion and the Lead-Lag Effect in Stock Returns. Review of Financial Studies.1113-1138.
Johnson , S., Stretcher, R., 2009. News and Noise: do investors react to stock split announcements differently during periods of high and low market volatility? Springer Economic Finance. 35, 71-78.

Lacina, M.J., Barry R. Marks, B.R., Shin, H., 2009. The Information Content of Quarterly Foreign Earnings of U.S. Multinational Companies under SFAS No. 131. Journal Of International Accounting Research. 8(2) , 23-44.

Lang, M., Lundholm, R., 1993. Cross-sectional determinants of analyst ratings of corporate disclosures. Journal of Accounting Research. 31, 246271.

Lev, B., Penman, S., 1990. Voluntary Forecast Disclosure, Nondisclosure, and Stock Prices. Joumal of Accounting Research. 28, 49-76.

MacKinlay, C., 1997. Event Studies in Economics and Finance. Journal of Economic Lecture, 35,13-39.

Mikkelson, W. H., Partch, M., 1986. Valuation effect of security offerings and the Issuance Process. Journal of Financial Economics.15, 31-60.

Obaidullah, M., 1990. Stock Price Adjustment to Half Yearly Earnings Announcements: A Test of Market Efficiency. Chartered Accountant. 38, 922-924.

Pigou, A.C., 1929. Industrial Fluctuations, second ed. McMillan Publishers, London.

Prabhala, N. R., 1997. Conditional Methods in Event Studies and Equilibrium Justification for Standard Event Study Procedures. The Review of Financial Studies. 10(1), 1-38.

Pradhan, H.K., Narasimhan, L.S., 2002. Stock Price Behavior in India since Liberalization. Asia-pacific Development Journal. 9(2), 83-106.

Ramnath, S., 2002. Investor and Analyst Reactions to Earning Announcements of Related Firms: An Empirical Analysis. Journal of Accounting Research. 40,1351-1376.

Thomas, J., Zhang, F., 2008. Overreaction to intraindustry information transfers? Journal of Accounting Research. 46(4), 909-940.

Veronesi, P., 1999. Stock market overreaction to bad news in good times: A rational expectations equilibrium model. Review of Financial Studies.12, 975-1007. 